\title{
Merkel Cell Carcinoma cM1 TNM Finding v8
}

National Cancer Institute

\section{Source}

National Cancer Institute. Merkel Cell Carcinoma cM1 TNM Finding v8. NCI Thesaurus.

Code C136836.

Merkel cell carcinoma with distant metastasis detected on clinical and/or radiologic

examination. (from AJCC 8th Ed.) 